\title{
SEEKING JUSTICE THROUGH QANUN JINAYAT: THE NARRATIVES OF FEMALE VICTIMS OF SEXUAL VIOLENCE IN ACEH, INDONESIA
}

\author{
Yogi Febriandi \\ State Institute for Islamic Studies Langsa \\ yogifebriandi@iainlangsa.ac.id \\ Muhammad Ansor \\ State Institute for Islamic Studies Langsa \\ ansor@iainlangsa.ac.id \\ Nursiti \\ Syiah Kuala University, Banda Aceh \\ nursitish@unysiah.ac.id
}

\begin{abstract}
This article examines the experience of Acehnese female victims of sexual violence seeking justice through Qanun Jinayat (Islamic criminal bylaw) in Aceh, Indonesia. The empirical data in this study were collected through in-depth interviews with the victims and families related to the cases of sexual violence. By employing the narrative agency, this article argues that telling the experience of seeking justice is a way female victims of sexual violence express their resistance to the implementation of Qanun Jinayat in Aceh. Regarding this, we will show that Aceh's Qanun Jinayat, which was originally implemented to eradicate sexual violence, turns out to have limitations in realizing the desired goals. This finding ultimately confirms that the concept of legal pluralism adopted in Aceh, Indonesia, has liminality in facilitating justice for women and other marginalized communities.
\end{abstract}

Keywords: Acehnese women, female victims of sexual violence, Qanun Jinayat. 


\section{A. Introduction}

Violence against women due to religious law is a latent problem faced by Muslim-majority countries (Afrianty, 2018b; Fadlia \& Ramadani, 2018; Minocha, 2020). Holden and Chaudhari (2013) argue that religious legislation in the state legal system often presents situations where women are being discriminated against in both the domestic arena (Aisyah \& Parker, 2014; Kapur \& Zajicek, 2018; Sheikhbardsiri et al., 2017), as well as in daily life in public spaces (Takyi \& Lamptey, 2020). According to Okin $(1998,1999)$, patriarchal culture in Muslim communities results in women being in an unfavorable situation.

Studies focusing on this area show that violence against women in the Muslim majority population is influenced by women's submission to patriarchal structures (Hayati et al., 2011; Nurlaelawati, 2016). Some studies argue that resistance to patriarchism is equivalent to the liberation of women (Benhabib, 1992, 1995). Although these arguments are vulnerable to criticism (Abu-Lughod, 2002, 2013; Avishai, 2008; Mahmood, 2001, 2004, 2006), a number of scholars believe in the intersection between patriarchism and violence against women (Barlas, 2002, 2006; Wadud, 1999, 2007).

This article examines the experience of Acehnese female victims of sexual violence seeking justice through Qanun Jinayat (Islamic criminal bylaw) in Aceh, Indonesia. This study used empirical data based on seven cases of sexual violence in Aceh after the enactment of Qanun Jinayat. In-depth interviews were conducted in 2017-2018 with 19 study participants consisting of victims and family members concerned. Our interview explored the information from the victims and their families, including 
a general description of events, victims' experiences in seeking justice, obstacles, and their reflection on experiences gained in the process of seeking justice. The interview with the victims was administered in the presence of the family members. Meanwhile, interviews were only undertaken with family members concerned because the victim was unwilling to be interviewed. In addition, the authors also interviewed other informants, such as legal counsels who handled the case (paralegals), community leaders, academics, gender activists, law enforcement officials, and local government staff. For the convenience of sexual violence victims, their identities were anonymized.

This paper positions the personal narratives as a case study to explore seeking justice through the Islamic criminal bylaw. Personal narratives are often considered subjective (Zsadanyi, 2015). However, Willemse (2007) argues that the subjective narrative has the power to build a more detailed representation of an event. Consequently, this study will argue that retelling of unpleasant experiences during the process of seeking justice in expressing the resistance of marginalized groups against the implementation of Qanun Jinayat. It utilizes the personal experiences of female victims of sexual violence in Aceh to problematize the limited access to justice through the Qanun Jinayat and the social costs arising from the legal pluralism applied among Muslim communities dominated by patriarchal culture.

\section{B. Qanun Jinayat and Aceh's Legal Pluralism}

Aceh's Qanun Jinayat No. 6/2014 has been enacted since 2014 to regulate certain aspects of Islamic criminal bylaw. The 
existence of Qanun Jinayat in the Indonesian legal system is often perceived as an anomaly. Although Indonesia is "neither an Islamic nor a secular state" (Seo, 2012, p. 1045, 2013, p. 44), one of its regions has the privilege of implementing Islamic law (Ansor, 2016; Ansor et al., 2016; Ansor \& Amri, 2020; Salim, 2018; Pohan, 2020). The implementation of Islamic law was tolerated because of the specific socio-cultural, political, and historical context of Aceh in modern Indonesia (Salim, 2004). In this case, it was believed to be a part of the search for peace between the Government of Indonesia and the Aceh separatist movement (Kingsbury, 2007; Miller, 2009; Siregar, 2008).

Salim $(2010,2015)$ argues that the law in Aceh portrays how the principle of legal plurality is applied in Indonesia. The principle of legal plurality requires that each case has more than one legal channel option in its resolution. For example, a case of sexual harassment in Aceh is open to options for resolution through the mechanism of Islamic criminal bylaw (Qanun Jinayat); the settlement based on the Indonesian national criminal law (KUHP, Kitab Undang-undang Hukum Pidana); or the Child Protection Act (Law No. 35 of 2014) when the cases involve children as perpetrators and/or victims. In addition, Aceh's Qanun No. 9/2008 regarding the development of the custom and tradition in certain conditions becomes an alternative in solving legal problems that prevail in the communities (Fadlia \& Ramadani, 2018).

One of the topics in Qanun Jinayat that has attracted public attention is the regulation of criminal acts of sexual violence. The regulation is considered to have limited women's access to justice and violated the principles of the Convention on the Elimination of All Forms of Discrimination 
against Women (CEDAW) and the principle of human rights. Regarding this, Qanun Jinayat is not firm in distinguishing the law of morality (based on religion) from criminal law. Female victims of sexual violence are not recognized as victims who are deprived of their dignity but rather as subjects who have contributed to causing situations of violence to occur. In addition, Qanun Jinayat is a product of religious conservatism (Butt, 2018). This perspective is commonly found in the culture of patriarchal societies that are not pro-women (Seedat, 2016).

The plurality of law has contributed to the worsening position of women in seeking justice (Butt, 2018; Holden \& Chaudhary, 2013; Moustafa, 2013; Nurlaelawati \& van Huis, 2019; Parashar, 2013; Singh, 2019). As shown by Nurlaelawati and Van Huis (2019), legal pluralism adopted in Indonesia makes it difficult to guarantee the fulfillment of basic rights to women due to challenges arising from Islamic law and customary law, which still significantly affect judicial decisions.

In the meantime, patriarchism influences the process of resolving cases of sexual violence through Islamic justice mechanisms in Aceh (Afrianty, 2011, 2015, 2016, 2018a; Ansor, 2014; Fadlia \& Ramadani, 2018). It is recognized that the enactment of Qanun Jinayat does not necessarily negate the existence of other laws, but the option of legal settlement based on the Qanun Jinayat mechanism is considered more dominant than other options (Grossmann, 2014, 2016; Madanih et al., 2018; Salim, 2015).

The enactment of Qanun Jinayat invited controversy. For its supporters, it is a major breakthrough because the Qanun (a) adopts the definition of rape more broadly than 
stipulated in the Criminal Code, and (b) regulates victims' rights to restitution, which is not regulated in the Criminal Code (Madanih et al., 2018). Meanwhile, the critics assess that the regulation of rape and sexual harassment through Qanun Jinayat tends to harm the victims (Afrianty, 2011, 2018a; Fadlia \& Ramadani, 2018; Grossmann, 2016). The penalties for perpetrators of sexual violence are considered lighter than those in the Criminal Code, which indicates the weakness of gender sensibility in the regulation. In addition, the application of caning for perpetrators based on the Qanun Jinayat has not only shifted to become a symbol for the local government's attention to the implementation of Islamic law but also to an arena for staging punishments for the community (Fadlia et al., 2020).

In Qanun Jinayat, caning is not the only sentence applied as means of punishing perpetrators. In fact, sanctions ('uqubat) against convicted of sexual harassment and rape in Qanun Jinayat are categorized into two, including ta'zir and additional ta'zir. Ta'zir punishment has four alternatives, such as caning, fines, imprisonment, or restitution. Meanwhile, the additional ta'zir penalties include (a) fostering by the state, (b) restitution by parents/guardians, (c) returns to parents/ guardians, (d) termination of marital relations, (e) revocation oflicenses, (f) confiscation of certain goods, and (g) social work. In cases of sexual harassment, the punishment is 45 lashes and 90 times for cases of child sexual abuse. Meanwhile, rape cases are subject to caning for 125-175 times and 150-200 times for child rape cases (See Qanun Jinayat, 2015). Qanun Jinayat makes imprisonment one of the options for punishing criminal offenders. However, because caning is considered a 
symbolism of Islamic law, a number of judges are more likely to prefer caning in their decisions (Armia, 2019).

Qanun Jinayat also opens the option of converting caning into imprisonment in the proportion of one lash equivalent to one month in prison or one lash for 10 grams of gold (Qanun Jinayat, 2015). Thus, for rape cases, an offender can be subject to imprisonment of between 125-200 months or a fine of 1,250 grams to 2,000 grams of pure gold (Butt, 2018). The regulation states that the form of punishment is alternative, not cumulative. Regarding this, Public Prosecutors (JPU, Jaksa Penuntut Umum) select one of the three available alternatives, in which the judges further set the sanction according to the type of sanction proposed by the Prosecutors. In addition, Qanun Jinayat does not set up a preventive mechanism to ensure that the perpetrators will not repeat their actions to the victims after serving a sentence.

In relation to the ambivalence of Qanun Jinayat in promoting gender justice, women activists are critical in the process of formulating the regulation. Grossman (2016) discussed the advocacy and activism of feminist women in Aceh in the process of drafting Qanun Jinayat. Afriyanti ( $2015,2018 b$ ) explored the participation of Acehnese women activists in the formulation of the Qanun of Islamic law. However, the voice of female activists is often heard in a limited way (Afrianty, 2015). Their voices were immersed in the hustle and bustle of local politics and the public's insistence that the Qanun Jinayat must be enforced immediately (Idria, 2016). As a result, Qanun Jinayat does not portray sensitivity to gender equality (Grossmann, 2016). However, as a product of legislation developed through the democratic mechanism, 
every citizen is required to comply with the regulation as a symbol of compliance with the implementation of Islamic law.

Several studies on Muslim women have explored women's voices as a form of resistance to patriarchal culture (Abu-Lughod, 1993; Ahmed, 1992). In relation to this, our article aims to show that the narratives constructed by women in certain conditions represent the expressions of resistance to inequality. Women's voices serve as an agency that is built on criticizing the structures that bound them (NagarRon \& Motzafi-Haller, 2011). Benhabib (1992) outlines that the articulation of critical resistance can be built from the narrative agency created by women. According to Fleetwood (2016), the awareness of structure disparity does not arise autonomously from self-awareness but rather from the forms of creativity towards the structure. In other words, the narration is not born naturally but self-identification, where "I" becomes a representation of the self (Benhabib, 1992).

The way in which female victims of sexual violence share their experiences of seeking justice can be used as an analytical tool to identify their resistance to Qanun Jinayat. While the study of sexual violence has not paid attention to self-narrative as a critical action against structure, this study argues that self-narrative is not only an expression of agency but also an expression of resistance to injustice and domination. Therefore, our paper introduces new perspectives on studies of sexual violence in Aceh, Indonesia, by analyzing the narrative agencies of female victims as the art of resistance. 


\section{Qanun Jinayat through women's narratives}

This section examines the experience of female victims of sexual violence in seeking justice through Qanun Jinayat in Aceh. Our discussion covers four themes, namely: (a) highlighting gender disparity in Islamic justice institutions; (b) Taking actions against disproportionate punishment; (c) questioning re-victimization of victims of sexual violence; and (d) claiming the victim's forgotten right to restitution and recovery. Through these topics, women's critical narratives are perceived as performances of agency and the art of resistance toward Qanun Jinayat.

\section{Highlighting Gender Disparity in Islamic Justice Institutions}

Our research participants stated that the crucial issues in the implementation of Qanun Jinayat were that various law enforcement institutions, such as Wilayatul Hisbah or sharia police, police, court, and prosecutors, had limited understanding of gender perspective. This is a latent issue of the judiciary (Oosterveld, 2014; Yilmaz, 2014). In this regard, female victims of sexual violence who seek justice often experienced situations where the personnel of the Wilayatul Hisbah (WH) institution did not have the competence to act as investigators. The research participants deplored the situation where the judiciary handled legal issues without considering the principle of gender equality. In addition, the WH personnel often have a diverse understanding of the status of rape cases between the act of criminal offense and complaint offense. In addition, some WH personnel thought that a 
rape case was considered 'a complaint offense' so that the handling of the case could only be processed if there was a complaint.

It was recognized that the $\mathrm{WH}$ personnel was not well prepared to handle the investigation of rape cases. The initial idea of forming this institution was as a field implementer in the enforcement of Islamic law (Feener, 2012, 2013; Otto \& Otto, 2016). However, WH's basic understanding of the formal legal mechanism regarding the issues handled is crucial to the success of Qanun Jinayat's implementation (Madanih et al., 2018). The limited understanding of gender equality has resulted in constrained gender equality in law enforcement (Rahman, 2012). The majority of WH personnel are men who, according to a study conducted by Nilan et al. (2014), tend to have discriminatory perspectives related to sexual violence.

The lack of understanding regarding gender equality also influences legal processes. In this case, a research participant complained about her case being handled by male law enforcement officers who did not have a gender perspective. Riza (anonymous name), a victim who reported her rape case to the police, shared her objections about police investigators who handled her case. The psychological condition of women as victims was disregarded by the investigators. As a result, Riza had difficulty telling the chronology of her case in a detailed and open manner. One of the police officers considered the rape case experienced by Riza as consensual sexual intercourse because the incident occurred repeatedly. Furthermore, the investigators drew 
conclusions merely based on the frequency of events without exploring the context of repeated rape events more deeply. At the same time, women in Indonesia who become victims of sexual violence often consider social risks when describing the traumatic experiences they have endured (Hayati et al., 2011).

A similar phenomenon was found in another case, by which in one of the trials of a rape case, the judge (male) urged the woman (victim) to retell the chronology and details of the rape incident. The judge, however, did not consider the effects of the narration on the mental recovery process of the victim. The narratives of rape and sexual violence victims were conveyed in an unequal condition of gender relations in law enforcement institutions (Madanih et al., 2018). The condition of women as victims is even more psychologically stressed when dealing with male law enforcement officers.

Unequal gender relations is a latent problem faced by court institutions (Yilmaz, 2014). Our research shows that Mahkamah Syar'iyah (the Islamic justice institution that handles cases based on the Qanun Jinayat in Aceh) encountered considerable problems when handling cases based on the gender equality perspective. This study also revealed that the ratio of male and female judges at the research location was ten to one. Nurlaelawati (2013) argues that the presence of women judges determines the success of the gender justice process.

In this study, research participants criticized the judge's lack of knowledge in handling cases based on Qanun Jinayat. This phenomenon was partly caused by a 
number of judges who did not have special education and direct experience in resolving criminal cases, especially rape and sexual harassment. Regarding this, Sharia Court judges are used to handling civil cases such as divorce cases and inheritance disputes. The Sharia Court carried out efforts to increase the capacity of judges by sending a number of judges to attend the Qanun Jinayat training organized by Dinas Syariat Islam Aceh or DSI (the Office of Sharia Islam, Aceh). However, the number of accommodated participants for training annually is limited, thereby hampering the capacity development of gender perspective among the judges.

This condition is not exclusively experienced by Aceh. Singh (2019) stated that the model of legal pluralism also impedes the reforms in religious courts that manage cases of sexual violence. Generally, judges consider case handling based on Qanun Jinayat as identical to punishing a convicted person using an unfair method. In Afghanistan, the sentence imposed marginalizes women's rights (Singh, 2019), while in Aceh, the caning sentence given to the perpetrators does not give a sense of justice, which does not worth the loss of women's dignity. As discussed in the following subsections, the objections of victims or their family members to the application of punishment by caning are often ignored.

\section{Taking Actions Against Disproportionate Punishment}

Research participants consider nonoptimal legal sanctions as another challenge in seeking justice through 
Qanun Jinayat. The effectiveness of caning in generating a deterrenteffect is often debated (Armia, 2019; Grossmann, 2016; Idria, 2018). The majority of participants stated that caning convicted sexual violence perpetrators were not comparable to the committed criminal acts. The criticism was repeatedly conveyed to people they met when discussing experiences dealing with legal issues. An informant suggested that despite the caning sentence on the rape perpetrators could be resolved in only a day, the trauma and suffering experienced by the victims could last a long time, maybe even throughout their lives. They criticized that the sanctions set out in Qanun Jinayat are lower than the legal sanctions in Indonesia's national criminal law. Atengah outlined that:

"If the perpetrators of rape are only punished by caning, then it is equal to unpunished. The caning punishment that the perpetrator received is not commensurate with the crimes he had committed and the suffering we endured. Meanwhile, as reported on television, why is the punishment for other sexual assailants in the form of imprisonment for decades?" (Interview with Atengah, 11/04/2018).

The formal mechanism in Qanun Jinayat gives the impression that imprisonment sanctions are not available in the practice of resolving cases through this Qanun (Butt, 2018). One of the cases discussed in this study revealed that the victim and her family's limited understanding of the legal processes and available options in the Qanun was one of the reasons for this impression. The parents of rape victims want the case reported to be settled through the Criminal Code so that when the allegations 
are filed successfully proven in court, the offender will be sentenced to prison. However, these expectations cannot be fulfilled as the police investigator told the family that since the case reported was included in the offense regulated by Qanun Jinayat, the sentence would be in the form of caning.

If the family does not want the case to be resolved using Qanun Jinayat, then the alternative resolution is through a customary law mechanism. The family firmly refused to resolve the case through customary law because, through this law mechanism, one of the available sanctions will be marrying the rape perpetrator to the victim (Kloos, 2014). In the end, the family had no better choice but to settle it through Qanun Jinayat, and the perpetrators were subject to punishment of 150 lashes. Our study found that the victims repeated their stories about their negative experiences and disappointments as a way of expressing resistance to the resolution of cases in court institutions based on Islamic criminal bylaw mechanisms. In an interview, two family members of a rape victim in Aceh Tengah and Aceh Utara stated:

"If the perpetrator is not being imprisoned and only punished by Qanun Jinayat (caning), we are not satisfied because it is unfair. He (the perpetrator) can return to the village again. We are worried that we made a mistake and resorted to violence when we saw him around here." (Interview with Autara, 14/04/2018).

Empirical data found three reasons for victims' dissatisfaction with handling rape cases through Qanun Jinayat. First, regardless of the number of lashes decided 
by the court, a caning sentence is considered less comparable to the crime committed by the convicted individual. Second, despite the existence of imprisonment as an alternative to caning, the court is more likely to select caning as the sentence. Third, other legal alternatives, such as fines in the form of gold, are also considered to be less deterrent to convicts (Madanih et al., 2018). Furthermore, the fines paid by perpetrators cannot be utilized by victims because Qanun Jinayat generally regulates the fines to be managed by Badan Baitul Mal (religious charity agency) in the region. As Sbriccoli (2013) points out, legal pluralism sometimes does not benefit marginalized groups in accessing justice because of the limited competence of the legal apparatus.

The objection to caning is due to the disproportional punishment compared to the suffering and loss experienced by victims (Butt, 2018; Grossmann, 2014, 2016). Rata, one of the victims being interviewed, said that "the caning sentences imposed on the perpetrators were not comparable to the crimes committed and the suffering we experienced" (Interview with Rata, 11/04/2018). Another informant, a parent of a female rape victim, felt she did not get any justice because the perpetrator was only flogged. He said, "We are afraid we will make mistakes and commit violence to the perpetrator when we see him around" (Interview with Ratu, 04/14/2018). This situation may occur because the victim or her family is disappointed to witness the perpetrator who has completed the sentence in a short time (Madanih et al., 2018). 
Caning often does not succeed in generating a significant deterrent effect on the offenders. Another participant, Raka, who works as a lawyer and has accompanied a legal case faced by a perpetrator of rape against minors, testified that the 150 lashes received by his client did not have a strong deterrent effect on the offender. Not long after finishing the caning sentence, the rapist met with Raka to express his gratitude for the assistance that allowed him to survive the legal trap subject to 15 years in prison related to a case with a minor child victim (Interview with Raka, 10/04/2018).

Good intentions sometimes lead to new problems. Caning, which is expected to bring a sense of justice, is perceived by many people in various ways. Regarding this, the elites have an opposite image with the victim in recognizing caning as a form of punishment. Taylor (2015) used heterotopia as the term to describe the gap between the imagination of the elite and the public about the construction of Islamic law in Aceh. He further outlines that the differences between the imagination of the public and policymakers illustrate the resistance of the former to the latter (R. W. Taylor, 2012). In relation to this, the marginal group always has a way of expressing resistance to the superordinate group (Scott, 1985, 1990). Allusions, criticisms, or curses are among the expressions of resistance from marginalized groups (Scott, 1985, 2009). The criticism of sexual violence victims and their families against the legal process using Qanun Jinayat can be interpreted as the art of resistance to the complexity in seeking justice. 


\section{Questioning Re-victimization of Victims of Sexual Violence}

A number of studies state those female victims of sexual violence experience multiple layers of victimization (re-victimization) (Acharya, 2014; Takyi \& Lamptey, 2020). Re-victimization is not only experienced during the events of rape but also during the process of seeking justice, from the police to the court, in social spaces, and in the family environment. Re-victimization can be interpreted as a situation where victims reencounter violence in various forms after the previous violence. Poerwandari (2013) assesses that female victims of rape often experience repeated victimization due to acts that occur beyond their control and will.

Victimization can be committed by anyone, whether individuals, families, communities, or government officials (Francis \& McKenna, 2018; Zempi, 2017). The notion that women are a symbol of honor has resulted in rape victims being accused of causing disgrace and tarnishing the reputation of the community (Dogan, 2014). Since rape is considered a disgrace to the community, therefore, in a number of cases found in this study, rape victims were regarded by their communities to be a source of disaster, and some even were expelled from their communities, lost their jobs, and being isolated from their social environment (Madanih et al., 2018). In some other countries, such as in Pakistan or Turkey, more extreme cases are discovered, in which rape victims sometimes suffer victimization in the form of honor killings committed by their own family members (Dogan, 2011, 2014; Raza, 2006). 
Our study found that victimization of victims in Aceh post-shariatism was due to: (a) the low professionalism of law enforcement officials; (b) the negative perceptions toward rape victims by considering them as the ones who provoke rape; (c) the direction of resolving rape cases through customary mechanisms; (d) the expulsion of the victims from their hometown because they are regarded to damage the reputation of the community; (e) the termination of employment or other social relations, (f) the pressure to marry the victims to perpetrators; and many others. Although the practice of re-victimization of rape victims in Aceh does not escalate to honor killing, it remains a worrying phenomenon and must be stopped.

Based on the narratives of the victims, we found several aspects needed to be improved in eliminating the victimization of rape victims by law enforcement officers. Investigators, for example, are required to have special skills in extracting facts from victims so that the questions asked will make victims intimidated and burdened by remembering the traumatic events. The negative perceptions among legal officers, such as perceiving a rape case as a result of the victims' appearance or attire that result in sexual harassment, is a form of re-victimization. In one of the cases experienced by Rina, the law enforcement officials actually considered the reported rape case to occur based on a relationship of mutual pleasure, given that during the case handling process, it was discovered that the incident occurred more than once (Interview with Rina, 11/04/2018). 
Some participants suggested that the practice of re-victimization was carried out by law enforcement officers. One of the cases discussed in this study revealed that an investigator had directed the reported cases to be resolved through customary mechanisms. The settlement process through the customary mechanism usually refers to Qanun No. 9/2008 regarding the Development of Customary and Indigenous Life. In relation to the Qanun, it is known that the customary court does not have the authority to address rape cases. The authority of the customary court is only limited to minor criminal acts and civil cases that can be resolved through peace mediation. Ironically, in many rape cases that have been resolved through customary courts, the sanctions imposed by the decision have burdened the victims since they must be married to the perpetrators. In other cases, the perpetrators are merely charged to compensate the victims in a peaceful way of settlement.

Rima, 15 years old, was a victim of an attempted rape case by a single young man, 30 years, who is a person she knows. The victim's family, who intended to report the case to the court, was informed by one of the police officers to reconsider the idea. In this case, the officer argued that the victim's family had the potential to be sued back by the reported party if the victim or her family is unable to provide sufficient evidence to support the report. The police investigator advised the family to take the available measure to resolve the case through the customary mechanism at the village level. Through this mechanism, the perpetrator was required to pay a 
customary fine of two and a half million rupiah to the victim's parents (Madanih et al., 2018).

Basically, re-victimization of victims of sexual violence or rape can occur anywhere. However, Bitsch and Klemetsen (2017) warned that the victimization of sexual violence victims is a manifestation of patriarchal culture. The above case shows that the settlement by using a customary mechanism was initially considered a good intention to resolve the case and have a deterrent effect on the perpetrators. However, it turns out that the available social mechanisms in the community are actually not in favor of the victims. The said mechanism states that a case is considered resolved after the agreement or decision is implemented. Nevertheless, the extent to which it can end the suffering of the victims is a significant issue that needs to be discussed further. During the period of this study, Atiga, a woman who was a victim of sexual harassment, still had a deep trauma even though her case had been settled through Adat or customary mechanisms more than a year earlier.

\section{Claiming the Victim's Forgotten Right to Restitution and Recovery}

One of the breakthroughs in Qanun Jinayat in handling rape or sexual harassment cases is the presence of articles regarding the restitution and recovery of victims. For instance, Article 1 defines restitution as a sum of money or assets that must be paid by the offender, his family, or a third party who gets a mandate based on the judge's order to the victim or his family. The payment is intended as compensation for 
"suffering, loss of certain assets, or reimbursement for certain actions" arising from the case.

Article 51 Paragraph (1) regulates the maximum limit of restitution in more detail that must be paid by a rape convict, which is 750 grams of pure gold or the equivalent value at the time of payment made. In addition, another Paragraph in the same Article states that the determination of restitution by judges is implemented with consideration of the economic capabilities of the criminal offender. It is also stated that if the convicted individual committed rape in forced circumstances or under conditions that were difficult to avoid, restitution should be imposed on both the coercive party and the perpetrator.

The Article about restitution indicates that Qanun Jinayat also considers the recovery of the victim. This study, however, discovered that restitution has never been obtained by the rape victims in this study due to several reasons. First, the limited knowledge of victims and their families about the mechanism and legal process in Qanun Jinayat is suspected to be quite an influential factor. Secondly, the commitment of law enforcement officials in realizing restitution is also relatively low. Third, so far, there is still no best practice on restitution either at the provincial or district/city levels in Aceh, so there is no example of learning on this matter. The absence of a governor's regulation that can be used as a reference for calculating restitution also contributes to this phenomenon (Madanih et al., 2018).

The above phenomenon indicates the complexity of the situation encountered in realizing the restitution for victims. The limited knowledge among the victims, the unavailability of technical references, and the lack of commitment among 
law enforcers are related to the low contribution of legal services in realizing "social engineering" (Feener, 2012, 2013). In several cases, it was revealed that the victim received a sum of money from the perpetrator as compensation for what she had suffered. However, it was not administered through formal legal mechanisms (Madanih et al., 2018). From the findings of this study, it was found that a case of sexual violence was resolved through customary mechanisms. The customary court adjudicating the case decided on sanctions to the perpetrators in the form of monetary compensation with a total value of seven million rupiahs. Once the compensation had been paid, then the problem was considered legally resolved. Despite the fact that the customary issues had been resolved, the problems were not automatically settled.

Such compensation as a means of settling sexual violence cases, as illustrated above, is a practice of revictimization. Seven million rupiah is clearly incomparable to the suffering and trauma experienced by the victims. While the victims suffered deep trauma, the legal sanctions imposed on the perpetrators were declared over once these sanctions from the customary court were fulfilled. The victimization, however, does not stop there. A case encountered in North Aceh revealed that re-victimization occurred because of the negative stigma addressed to the victim and her family due to the settlement in the form of monetary compensation. The victim or their family members were assumed to have traded the "price of virginity" because they accepted the settlement through a certain amount of money paid. A victim's family member who participated in our study stated: 
"I don't know what his family (perpetrator) said to my daughter and me. It seems that they mock us in front of people while there is an event in the village. I tried to be strong. Be patient. Because if I respond, it only adds to my hatred. I'm sure there are people who trust and support me in the village. They know I've fought for justice for my daughter". (Interview with Aselatan, 11/04/2018).

In many ways, women are often disadvantaged in sexual violence cases. The imbalance of power relations is one of the causing factors. Although Qanun Jinayat regulates the sanction of restitution for the convicted cases of sexual violence, its implementation is not always as expected. In order to enforce the restitution properly, the government needs to issue derivative policies as the operational basis for performing this regulation.

\section{Self-narrations as Agency and the Art of Resistance}

The victim's explanation to the researcher by emphasizing their dissatisfaction with the legal process illustrates the way in which female victims articulated their resistance in response to Qanun Jinayat in Aceh. The search for justice through Qanun Jinayat is portrayed as a steep alley because of the severe challenges faced by women as victims. The problem becomes more perplexed as the final verdict in the form of legal sanctions for the perpetrators is considered incomparable to the suffering experienced by the victims.

Self narrations of female victims sexual violence over the negative experiences they endured becomes a means of articulating their resistance (Bhimji, 2009; Hays, 1994; Korteweg, 2008; McNay, 2000, 2004; Richmond, 2011) toward 
the settlement of sexual violence crimes using this Islamic criminal bylaw. Self-narration, according to Willemse (2007), is a form of women's agency. Similarly, Enck and McDaniel (2015) said that the act of telling one's own experiences is a form of personal agency in providing alternatives for a better future for themselves. For our research participants, the ability to criticize the undertaken legal process, the aptitude to imagine a future that is not haunted by traumatic feelings, and the ability to share narratives with parents or closest people illustrate the articulation agency to break away from traumatic experiences in order to design a better future.

In contrast to Fleetwood (2016) who sees women's narratives as habitus, and Butler (Butler, 1999), who considers narratives as performance, our article perceives narratives as the art of resistance against domination (Scott, 1985, 1990, 2013). The women in our study consciously developed a narrative of dissatisfaction with experience in seeking justice. The narrative of discontent feeling is developed from an autonomous attitude, not because of the denial or constant awareness in the structure, but instead as a capacity of discovering oneself. Through self-marking, women victims of violence can mediate social conditions with self-awareness.

Through self-narrations, the resistance to broader social structures can be developed. The subject becomes autonomous and cannot be reduced by the structure. The experience of the Acehnese female victims provides knowledge - albeit in particular cases - around the debate about the universality and particularity of the legal system concerning sexual violence. Until currently, although several studies have seen the importance of legal locality as an 
appreciation of diverse human traditions, it is necessary to limit or exclude sexual violence. Qanun Jinayat, as a product of legal pluralism, provides many problems related to the protection of female victims of sexual violence. Our findings, of course, contradict the arguments of most Acehnese scholars who believe that Qanun Jinayat has played a significant role as a means of social engineering in Aceh society (Armia, 2019; Feener, 2013; Muhammad, 2003).

\section{E. Conclusions}

This paper has scrutinized the narratives of female victims of sexual violence in seeking justice in Aceh. The writing shows that the narrative of disappointment is a way for women to express resistance to a patriarchal legal structure. Through self-narrations, they criticized gender disparity, re-victimization of victims, the lighter criminal sanctions against sex offenders in Qanun Jinayat compared to the penalties stipulated in the national criminal law system, as well as the forgotten recovery process for victims. This paper also revealed the victims' perception that caning punishment lacked a deterrent effect on the sexual violence perpetrators. Essentially, our study has shown that self-narration is a means of expressing criticism and resistance for the victims of sexual violence cases to the limitations of Qanun Jinayat in providing justice for women.

Qanun Jinayat, which was initially intended as a correction to the limitations of Indonesia's national criminal law, turned out to have a substantive weakness in providing essential services to guarantee legal protection for women 
who are dealing with the law. This condition certainly hinders the implementation of special authority in Aceh to bring justice and prosperity. The positive intentions in facilitating the Acehnese citizens to obtain justice and prosperity based on a system of values and embraced doctrinal beliefs do not always result in expected outcomes. Therefore, our paper recommends the importance of reopening a vast and fundamental discussion space to find a systemic solution in overcoming the problem.

\section{Acknowledgments}

The field data used in this study was a part of a larger study entitled "Menyusuri Jalan Keadilan: Upaya Peningkatan Layanan Bagi Perempuan Berhadapan dengan Hukum di Aceh", conducted by BSUIA (Balai Syura Ureung Inong Aceh), JMSPS (Jaringan Masyarakat Sipil Peduli Syariat), and RPuK (Relawan Perempuan untuk Kemanusiaan). The authors would like to express their gratitude to the other research team members (Dahlia Madanih, Ilham Munawar Siddiq, Laila Juari, Norma Susanti, Rasyidah, Rizkika Lhena Darwin, Ruwaida, Seri Rahayu, and Siti Maisarah) for their permission to utilize the data for this article.

\section{References}

Abu-Lughod, L. (1993). Writing women's worlds: Bedouin stories. University of California Press.

Abu-Lughod, L. (2002). Do muslim women really need saving? Anthropological reflections on cultural relativism and 
its others. American Anthropologist, 104(3), 783-790. https://doi.org/10.1525/aa.2002.104.3.783

Abu-Lughod, L. (2013). Do muslim women need saving? Harvard University Press.

Acharya, A. K. (2014). Sexual exploitation and trafficking of women and girls in Mexico: An analysis on impact of violence on health status. February 2015, 37-41. https:// doi.org/10.1080/07256868.2014.885414

Afrianty, D. (2011). Local women's movements in Aceh and the struggle for equality and justice: The women's network for policy 1. RIMA: Review of Indonesian and Malaysian Affairs, 45(1-2), 37-68. https://doi. org/10.1163/22134379-17401024

Afrianty, D. (2015). Women and sharia law in northern Indonesia: Local women's ngos and the reform of Islamic law in Aceh. Routledge.

Afrianty, D. (2016). local women's ngos and the reform of Islamic law in Aceh: Case of MISPI. In R. M. Feener, D. Kloos, \& A. Samuels (Eds.), Islam and the limits of the state: reconfigurations of practice, community and authority in contemporary Aceh (pp. 118-140). Brill. https://doi.org/10.1177/0308518X19836119

Afrianty, D. (2018a). Agents for change: Local Women's organizations and domestic violence in Indonesia. Bijdragen Tot de Taal-, Land- En Volkenkunde, 174(1), 24-46. https://doi.org/10.1163/22134379-17401024

Afrianty, D. (2018b). Women's responses to the implementation of Islamic law in Aceh. In R. W. Hefner (Ed.), Routledge Hanbook of Contemporary Indonesia (pp. 346-353). Routledge. https://doi.org/10.4324/9781315628837-28

Ahmed, L. (1992). Women and gender in Islam: Historical roots of a modern debate. Yale University Press. 
Aisyah, S., \& Parker, L. (2014). Problematic conjugations: Women's agency, marriage and domestic violence in Indonesia. Asian Studies Review, 38(2), 205-223. https://doi.org/10.1080/10357823.2014.899312

Ansor, M. (2014). Being woman in the land of shari'a: Politics of the female body, piety and resistance in Langsa, Aceh. Al-Jami'ah, 52(1), 59-83. https://doi.org/10.14421/ ajis.2014.521.59-83

Ansor, M. (2016). Post-islamism and the remaking of Islamic public sphere in post-reform Indonesia. Studia Islamika, 23(3), 471-515. https://doi.org/10.15408/sdi. v23i3.2412

Ansor, M., \& Amri, Y. (2020). Being christians in the Acehnese way: Illiberal citizenship and women's agency in the Islamic public sphere. Journal of Indonesian Islam, 14(1), 77-112. https://doi.org/10.15642/JIIS.2020.14.1.77-112

Ansor, M., Amri, Y., \& Arrauf, I. F. (2016). Under the shadow of sharia: Christian muslim relations from Acehnese Christian experience. Komunitas, 8(1), 125-134. https://doi.org/10.15294/komunitas.v8i1.4966

Armia, M. S. (2019). Public caning: Should it be maintained or eliminated? (A reflection of implementation sharia law in Indonesia). QIJIS: Qudus International Journal of Islamic Studies, 7(2), 301-328. https://doi.org/10.21043/qijis. v7i2.4974

Avishai, 0. (2008). "Doing religion" in a secular world: Women in conservative religions and the question of agency. Gender \& Society, 22(4), 409-433. https://doi. org/10.1177/0891243208321019

Barlas, A. (2002). “'Believing women"' in Islam: Unreading patriarchal interpretations of the qur'an. University of Texas Press. 
Barlas, A. (2006). Women's readings of the qur'an. in j. d. mcauliffe (ed.), the cambridge companion to the qur'an (pp. 255-271). Cambridge University Press.

Benhabib, S. (1992). Situating the self: Gender, community and postmodernism in contemporary ethics. Polity Press.

Benhabib, S. (1995). Feminism and postmodernism: An uneasy alliance. In S. Benhabib, J. Butler, D. Corner, \& N. Fraser (Eds.), Feminist contentions: A philosophical exchange (pp. 17-34). Routledge.

Bhimji, F. (2009). Identities and agency in religious spheres: A studyofbritishmuslimwomen's experience.Gender,Place \& Culture: A Journal of Feminist Geography, 16(4), 365380. https://doi.org/10.1080/09663690903003850

Bitsch, A., \& Klemetsen, M. E. (2017). The legal grading of sexual citizenship: Sentencing practices in Norwegian rape cases. Gender, Place \& Culture: A Journal of Feminist Geography, 24(2), 174-188. https://doi.org/10.1080/0 966369X.2017.1298572

Butler, J. (1999). Gender trouble: Feminism and the subversion of identity. Taylor and Francis e-Library.

Butler, J. (2004). Precarious life: The powers of mourning and violence. Verso.

Butt, S. (2018). Religious conservatism, Islamic criminal law and the judiciary in Indonesia: A tale of three courts. The Journal of Legal Pluralism and Unofficial Law, 50(3), 402-434. https://doi.org/10.1080/07329113.2018.15 32025

Dogan, R. (2011). Is honor killing a "Muslim phenomenon"? Textual interpretations and cultural representations. Journal of Muslim Minority Affairs, 31(3), 423-440. https://doi.org/10.1080/13602004.2011.599547 
Dogan, R. (2014). Different cultural understandings of honor that inspire killing: An inquiry into the defendant's perspective. Homicide Studies, 18(4), 363-388. https:// doi.org/10.1177/1088767914526717

Enck, S. M., \& McDaniel, B. A. (2015). "I want something better for my life": Personal narratives of incarcerated women and performances of agency. Text and Performance Quarterly, 35(1), 43-61. https://doi.org/10.1080/1046 2937.2014.975271

Fadlia, F., \& Ramadani, I. (2018). The qanun jinayat discriminates against women (Victims of rape) in Aceh, Indonesia. Journal of Southeast Asian Human Rights, 2(2), 448-470.

Fadlia, F., Ramadani, I., Susilawati, N., \& Sari, N. (2020). Deterring or entertaining? Can the caning punishment execution in Aceh meet its objective? Mazahib, 19(1), 45-84. $\quad$ https://doi.org/10.21093/mj.v19i1.2055 https://doi.org/10.19184/jseahr.v2i1.8358

Feener, R. M. (2012). Social engineering through sharīa: Islamic law and state-directed da'wa in contemporary Aceh. Islamic Law and Society, 19(3), 275-311. https:// doi.org/10.1163/156851911X612581

Feener, R. M. (2013). Shari'a and social engineering: The implementation of Islamic law in contemporary Aceh, Indonesia. Oxford University Press. Contemporary Aceh, Indonesia. Oxford University Press.

Fleetwood, J. (2016). Narrative Habitus: Thinking through structure/agency in the narratives of offenders. Crime Media Culture, 12(2), 173-192. https://doi. org/10.1177/1741659016653643 
Francis, L., \& McKenna, U. (2018). The experience of victimisation among muslim adolescents in the UK: The effect of psychological and religious factors. Religions, 9(8), 243. https://doi.org/10.3390/rel9080243

Grossmann, K. (2014). Muslim female activists and sharia in Indonesia: Scopes of acting in national and international perspectives. Review of Indonesian and Malaysian Affairs, 48(1), 95-125.

Grossmann, K. (2016). Women's rights activists and the drafting process of the Islamic criminal law code (qanun jinayat). In R. M. Feener, D. Kloos, \& A. Samuels (Eds.), Islam and the limits of the state: Reconfigurations of practice, community and authority in contemporary Aceh (pp. 87-117). Brill. https://doi. org/10.1163/9789004304864005

Hayati, E. N., Högberg, U., Hakimi, M., Ellsberg, M. C., \& Emmelin, M. (2011). Behind the silence of harmony: Risk factors for physical and sexual violence among women in rural Indonesia. BMC Women's Health, 11. https://doi. org/10.1186/1472-6874-11-52

Hays, S. (1994). Structure and agency and the sticky problem of culture. Sociological Theory, 12(1), 57-72.

Holden, L., \& Chaudhary, A. (2013). Daughters' inheritance, legal pluralism, and governance in Pakistan. The Journal of Legal Pluralism and Unofficial Law, 45(1), 104-123. https://doi.org/10.1080/07329113.2013.781447

Idria, R. (2016). Cultural resistance to shariatism in Aceh. In K. van Dijk \& N. J. G. Kaptein (Eds.), Islam, politics and change: The Indonesian experience after the fall of Suharto (pp. 247-268). Leiden University Press. 
Idria, R. (2018). Provisional notes on how "hilarious" living under sharia law (the case of Aceh). Kawalu, 5(2), 131158. https://doi.org/10.32678/kawalu.v5i2.1900

Kapur, S., \& Zajicek, A. (2018). Constructions of battered Asian Indian marriage migrants: the narratives of domestic violence advocates. Violence Against Women, 24(16), 1928-1948. https://doi. org/10.1177/1077801218757373

Kingsbury, D. (2007). The free Aceh movement: Islam and democratization. Journal of Contemporary Asia, 37(2), 166-189. https://doi. org/10.1080/00472330701253759

Kloos, D. (2014). In the name of syariah? Vigilante violence, territoriality, and moral authority in Aceh, Indonesia. Indonesia, 98, 59-90. https://doi.org/10.5728/ indonesia.98.0059

Korteweg, A. C. (2008). The sharia debate in ontario: Gender, Islam, and representations of muslim women's agency. Gender \& Society, 22(4), 434-454. https://doi. org/10.1177/0891243208319768

Madanih, D., Siddiq, I. M., Juari, L., Susanti, N., Nursiti, Rasyidah, Darwin, R. L., Ruwaida, Rahayu, S., \& Febriandi, Y. (2018). Menyusuri jalan keadilan: Upaya peningkatan layanan bagi perempuan berhadapan dengan hukum di Aceh (A. Yentriani (ed.)). Mahara Publisihing, BSUIA, JMSPS, RPuK.

Mahmood, S. (2001). Feminist theory, embodiment, and the docile agent: Some reflections on the egyptian islamic revival. Cultural Anthropology, 16(2), 202-236. https:// doi.org/10.1525/can.2001.16.2.202 
Mahmood, S. (2004). Women's agency within feminist historiography. The Journal of Religion, 84(4), 573579. https://www.journals.uchicago.edu/doi/ abs/10.1086/422481?journalCode=jr

Mahmood, S. (2006). Feminist theory, agency, and the liberatory subject: Some reflections on the islamic revival in Egypt. The Finnish Society for the Study of Religion, 42(1), 31-71. https://doi.org/10.33356/ temenos. 4633

McNay, L. (2000). Gender and agency: Reconfiguring the subject in feminist and social theory. Polity Press.

McNay, L. (2003). Agency, anticipation and indeterminacy in feminist theory. feminist theory, 4(2), 139-148.

McNay, L. (2004). Agency and experience: Gender as a lived relation. In L. Adkins \& B. Skeggs (Eds.), Feminism after Bourdieu (pp. 175-190). Blackwell Publishing.

Miller, M. A. (2009). Rebellion and reform in Indonesia: Jakarta's security and autonomy policies in Aceh. Routledge.

Minocha, A. (2020). Bhai Vir Singh and the public sphere in colonial Punjab. Sikh Formations: Religion, Culture, Theory, 16(1-2), 14-27. https://doi.org/10.1080/1744 8727.2019.1674515

Moustafa, T. (2013). Islamic law, women's rights, and popular legal consciousness in Malaysia. Law and Social Inquiry, 38(1), 168-188. https://doi.org/10.1111/j.17474469.2012.01298.x

Muhammad, R. A. (2003). Revitalisasi syari'at Islam di aceh: problem, solusi dan implementasi (H. Basri (ed.)). Logos dan IAIN Ar-Raniry. 
Nagar-Ron, S., \& Motzafi-Haller, P. (2011). "My life? there is not much to tell ": On voice, silence and agency in interviews with first-generation mizrahi jewish women immigrants to Israel. Qualitative Inquiry, 17(7), 653-663. https:// doi.org/10.1177/1077800411414007

Nilan, P., Demartoto, A., Broom, A., \& Germov, J. (2014). Indonesian men's perceptions of violence against women. Violence Against Women, 20(7), 869-888. https://doi.org/10.1177/1077801214543383

Nurlaelawati, E. (2013). Muslim women in Indonesian religious courts: Reform, strategies, and pronouncement of divorce. Islamic Law and Society, 20(3), 242-271. https://doi.org/: 10.1 Ié3/I5685195-0010A000

Nurlaelawati, E. (2016). The legal fate of indonesian muslim women in court: divorce and child custody. In T. Lindsey \& H. Pausacker (Eds.), Religion, Law and Intolerance in Indonesia (pp. 353-368). Routledge.

Nurlaelawati, E., \& van Huis, S. C. (2019). The status of children born out of wedlock and adopted children in Indonesia: Interactions between islamic, adat, and human rights norms. Journal of Law and Religion, 34(3), 356-382. https://doi.org/10.1017/jlr.2019.41

Okin, S. M. (1998). Feminism and multiculturalism: some tensions. Ethichs, 108(4), 661-684.

Okin, S. M. (1999). Is multiculturalism bad for women? In J. Cohen, M. Howard, \& M. C. Nussbaum (Eds.), Is Multiculturalism Bad for Women? (pp. 7-26). Princeton University Press.

Oosterveld, V. (2014). Constructive ambiguity and the meaning of "gender" for the international criminal court. International Feminist Journal of Politics, 16(4), 
563-580. https://doi.org/10.1080/14616742.2014.95 0818

Otto, B., \& Otto, J. M. (2016). Shari'a police in Banda Aceh: Enforcement of Islam-based regulations and people's perceptions. In R. M. Feener, D. Kloos, \& A. Samuels (Eds.), Islam and the limits of the state: reconfigurations of practice, community and authority in contemporary aceh (pp. 185-213). Brill.

Parashar, A. (2013). Religious personal laws as non-state laws: Implications for gender justice. The Journal of Legal Pluralism and Unofficial Law, 45(1), 5-23. https:// doi.org/10.1080/07329113.2013.773804

Poerwandari, K. (2013). If we are victims. Indonesian Feminist Journal, 1, 7-19.

Rahman, F. Z. (2012). Gender equality in muslim-majority states and shari'a family law: Is there a link? Australian Journal of Political Science, 47(3), 347-362. https://doi. org/10.1080/10361146.2012.704006

Raza, A. (2006). Mask of honor-causes behind honor killings in Pakistan. Asian Journal of Women's Studies, 12(2), 88-104. https://doi.org/10.1080/12259276.2006.116 66010

Richmond, O. P. (2011). Critical agency, resistance and a postcolonial civil society. Cooperation and Conflict,46(4),419440. https://doi.org/10.1177/0010836711422416

Salim, A. (2004). "Sharia from below" in Aceh (1930s-1960s): Islamic identity and the right to self-determination with comparative reference to the Moro Islamic Liberation Front (MILF). Indonesia and the Malay World, 32(92), 8099. https://doi.org/10.1080/1363981042000263471 
Salim, A. (2010). Dynamic legal pluralism in Indonesia: Contested legal orders in contemporary Aceh. The Journal of Legal Pluralism and Unofficial Law, 42(61), 1-29. https://doi.org/10.1080/07329113.2010.10756640

Salim, A. (2015). Contemporary Islamic law in Indonesia: Sharia and legal pluralism. Edinburgh University Press and The Aga Khan University.

Salim, A. (2018). The spesial status of Islamic Aceh. in r. w. hefner (Ed.), Routledge Hanbook of Contemporary Indonesia (pp. 237-245). Routledge.

Sbriccoli, T. (2013). Legal pluralism in discourse: Justice, politics and marginality in rural Rajasthan, India. The Journal of Legal Pluralism and Unofficial Law, 45(1), 143-164. https://doi.org/10.1080/07329113.2013.77 2788

Scott, J. C. (1985). Weapons of the weak: Everyday forms of resistance. Yale University Press.

Scott, J. C. (1990). Domination and the arts of resistance: Hidden transcripts. Yale University Press.

Scott, J. C. (2009). The art of not being governed: An anarchist history of upland Southeast Asia. Yale University Press.

Scott, J. C. (2013). Decoding subaltern politics: Ideology, disguise, and resistance in agrarian politics. Routledge.

Seedat, F. (2016). Sexual economies of war and sexual technologies of the body: Militarised muslim masculinity and the Islamist production of concubines for the caliphate. Agenda, 30(3), 25-38. https://doi.org/10.10 $80 / 10130950.2016 .1275558$

Seo, M. (2012). Defining 'religious' in Indonesia: Toward neither an Islamic nor a secular state. Citizenship Studies, 
16(8), 1045-1058. https://doi.org/10.1080/13621025 .2012 .735028

Seo, M. (2013). Falling in love and changing Gods: Interreligious marriage and religious conversion in Java, Indonesia. Indonesia and the Malay World, 41(119), 7696. https://doi.org/10.1080/13639811.2012.750104

Sheikhbardsiri, H., Raeisi, A., \& Khademipour, G. (2017). Domestic violence against women working in four educational hospitals in Iran. Journal of Interpersonal Violence.https://doi.org/10.1177/0886260517719539

Singh, D. (2019). The management of legal pluralism and human rights in decentralized Afghanistan. The Journal of Legal Pluralism and Unofficial Law, 51(350-380), 1-31. https://doi.org/10.1080/07329113.2019.16600 79

Siregar, H. B. (2008). Lessons learned from the implementation of Islamic shari'ah criminal law in Aceh, Indonesia. Journal of Law and Religion, 24(1), 143-176. https:// doi.org/10.1017/S074808140000196X

Takyi, B. K., \& Lamptey, E. (2020). Faith and marital violence in sub-saharan Africa: Exploring thelinks between religious affiliation and intimate partner violence among women in Ghana. Journal of Interpersonal Violence, 35(1-2), 2552. https://doi.org/10.1177/0886260516676476

Taylor, R. (2015). Syariah as heterotopia: Responses from muslim women in Aceh, Indonesia. Religions, 6(2), 566593. https://doi.org/10.3390/rel6020566

Taylor, R. W. (2012). A postcolonial inquiry of women's political agency in Aceh, Indonesia: Towards a muslim feminist approach? Virginia Polytechnic Institute and State University. https://vtechworks.lib.vt.edu/bitstream/ 
handle/10919/39190/Taylor_ReedW_D_2012. pdf? sequence $=1$ \&isAllowed $=\mathrm{y}$

Wadud, A. (1999). Qur'an and women: Rereading the sacred text from a women's perspective. Oxford University Press.

Wadud, A. (2007). Inside the gender jihad: Women's reform in islam. oneworld.

Willemse, K. (2007). One foot in heaven: Narratives on gender and Islam in Darfur, West-Sudan. Brill.

Yilmaz, I. (2014). Pakistan federal shariat court's collective ijtihād on gender equality, women's rights and the right to family life. Islam and Christian-Muslim Relations, 25(2), 181-192. https://doi.org/10.1080/09596410.2 014.883200

Zempi, I. (2017). Researching victimisation using autoethnography: Wearing the muslim veil in public. Methodological Innovations, 10(1), 205979911772061. https://doi.org/10.1177/2059799117720617

Zsadanyi, E. (2015). Gendered narrative subjectivity: Some Hungarian and American women writers. Academic Research. 